\title{
ECOSYTEM KEWIRAUSAHAAN DAN DAMPAKNYA PADA MINAT BERWIRAUSAHA
}

\author{
Mukhammad Kholid Mawardi \\ Fakultas Ilmu Administrasi Universitas Brawijaya \\ Email:mk_mawardi@ub.ac.id
}

\begin{abstract}
One of the leverage of a country's competitiveness is the level of entrepreneurship. Universities are one of the institutions that contribute to the development of entrepreneurship, but there has been no consistent research results on how Universitiy can boost entrepreneurship. The creation of entrepreneurship ecosystem is one of the manifestation of Universities' roles in improving entrepreneurship. Recent research involving 214 students in the Business Administration of Universitas Brawijaya aims to analysis the effects of entrepreneurship ecosystem on the entrepreneurial interest of students. By using multiple liner regression analysis, it was found that there is a simultaneous significant effect of all the variables of entrepreneurship ecosystem; cultural variable, material variable and social variable on entrepreneurship interest and partially, only the cultural variable (X1) and variable material (X3) that have a significant influence on the intention of entrepreneurial $(Y)$ and the not significan between the social variables $(X 2)$ and intention entrepreneurial $(Y)$.
\end{abstract}

\section{Keywords: entrepreneurship ecosystem, entrepreneuria}

\begin{abstract}
ABSTRAK
Salah satu pengungkit daya saing sebuah negara adalah tingkat kewirausahaan. Perguruan tinggi merupakan salah satu lembaga yang berkontribusi dalam pengembangan kewirausahaan, namun belum ada hasil penelitian yang konsisten tentang bagaimana perguruan tinggi mampu meningkatkan kewirausahaan. Penciptaan ecosystem kewirausahaan adalah salah satu mnifestasi peran perguruan tinggi dalam meningkatkan kewirausahaan. Penelitian yang melibatkan 214 mahasiswa prodi Administrasi Bisnis Universitas Brawijaya bertujuan untuk mengetahui pengaruh esosyem kewirausahaan terhadap minat kewirausahaan mahasiswa. Dengan menggunakan analisis regresi liner berganda, diketahui bahwa secara simultan terdapat hubungan significant antara semua variable ecosystem kewirausahaan yang terdiri dari variable budaya, variable materi dan variable social terhad minat berwirasuaha dan secara parsial, hanya variable budaya (X1) dan variabel materi (X3) yang memiliki pengaruh significant terhadap niat berwirausaha $(\mathrm{Y})$ dan hubugan tidak significan antara variabel Sosial (X2) dan Niat berwirausaha (Y).
\end{abstract}

Kata Kunci: ecosystem kewirausahaan,kewirausahaan 


\section{PENDAHULUAN}

Salah satu penungkit daya saing negara adalah kewirausahaan. Menurut Kementrian Koperasi dan UMKM, tingkat kewirausahaan di Indonesia masih relatif rendah yaitu sebesar 1,56 persen pada tahun 2013 dan meningkat menjadi 1,65 pada tahun 2014. Angka ini masih relatif lebih rendah dibanding Malaysia dan Singapore yang memiliki tingkat pertumbuhan kewirausahaan sebesar 5 dan 7 persen (The Jakarta Pos, 10/12/2004). Namun demikian, Indonesia sebagai negara berkembang yang berada pada the efficiency driven stage memiliki potensi untuk meningkatkan kewirausahaan karena adanya bonus demografi. Global Entrepreneurship Monitoring (GEM) yang melakukan studi kewiraausahaan dengan menggunakan variable aktivitas awal kewirausahaan (Total Early-stage entrepreneurial Activity/TEA) melaui indikator nascent entrepreneurship rate (penduduk yang terlibat dengan aktivitas pendirian usaha dan new business ownership rate atau tingkat kepemilikan usaha baru (antara tiga hingga 42 bulan).

Nilai nascent entrepreneurship rate Indonesia sebesar 5.7 persen, lebih rendah disbanding dengan Filipina (12 persen), Thailand (7.9 persen), Singapore (6.4 peren), Vietnam (4.1 persen) dan Malaysia (1.5 persen). Sedangkan nilai Indonesia untuk indikator new business entrepreneurship rate adalah 20.4 persen yang lebih tinggi disbanding Vietnam (11.5 persen), Thailand (10.4 persen), Filipinan (6.7 persen), Malaysia (5.2 persen) dan Singapore (4.4 persen). Apabila kedua indikator tersebut di rata-rata, maka Indonesia akan menjadi negara ASEAN yang memiliki rerata tertinggi di ASEAN dengan nilai TEA sebesar 25.5 persen.

Meskipun data GEM menunjukkan potensi kewirausahaan di Indonesia cukup positif, namun menurut survey lain (The Global Entrepreneurship \& Development Index (GEDI) 2018 dan The EY G20 Entrepreneurship Barometer 2013) kondisi kewirausahaan Indonesia belum baik. GEDI menemukan bahwa populasi wirausaha di Indonesia baru mencapai 1,65\% dari jumlah penduduk. Angka ini masih relatif rendah dibandingkan Malaysia, Thailand, dan Singapura yang jumlahnya di atas $4 \%$. Lebih lanjut survey GEDI mengungkapkan ekosistem kewirausahaan di Indonesia berada pada peringkat ke-68 dari 121 negara. Lebih lanjut, The EY G20 Entrepreneurship Barometer 2013, menempatkan Indonesia dalam kuartil keempat, yaitu kelompok negara ranking terendah dalam ekosistem kewirausahaan. Hal ini menunjukkan bahwa di Indonesia, wirausaha belumlah berperan optimal dalam mendukung perekonomian negara. Untuk meningkatkan tingkat kewirausahaan, mutlak diperlukan dukungan kelembagaan, termasuk didalamnya pendidikan (Acs et al, 2008). Banyak studi yang mengidentifikasi peran strategis Perguruan Tinggi dalam meningkatkan minat berwirasauaha mahasiswanya (Izedonmi and Okafor, 2010; Sánchez , 2011; Tokila \& Tervo, 2011; Paço et. al., 2015). Sánchez (2011) menemukan bahwa niat kewirausahaan dapat dipengaruhi oleh faktor indogen dan faktor eksogen. Dalam proses pendidikan seorang mahasiswa akan memperoleh pengetahuan dan ketrampilan untuk mengembangkan usaha baru (Paço et. al., 2015) dan pengembangan kemampuan individu, mengenali peluang baru dan pemahaman tentang proses kewirausahaan (Tokila \& Tervo, 2011). Namun, optimisme pendidikan tinggi dalam menghasilkan kewirausahaan melaui program kewirausahaan masih perlu dikaji lebih lanjut. Meskipun banyak PT menyelenggarakan program dan pendidikan kewirausahaan, namun minat mahasiswa untuk berwirausaha masih relatif rendah. Survei GUESSS (2016) yang melibatkan 122.509 orang mahasiswa dari 50 universitas di dunia menunjukkan bahwa $8.8 \%$ dari mahasiswa yang disurvei berniat untuk bekerja secara mandiri begitu setelah lulus kuliah. Sementara, sebanyak $38.2 \%$ berniat untuk bekerja secara mandiri setelah lima tahun lulus. Survei tersebut menyatakan bahwa salah satu penyebab rendahnya minat berwirausaha di kalangan mahasiswa adalah karena model pembelajaran kewirausahaan yang dirasa belum efektif dan belum mencapai sasaran. Berdasarkan fenomena tersebut, penelitian ini bertujuan untuk menjelaskan pengaruh ecosystem kewirausahaan terhadap minat berwirausaha mahasiswa Universitas Brawijaya

\section{KAJIAN PUSTAKA \\ Minat Berwirausaha}

Minat atau niat berwirausaha telah terbukti menjadi konstruk yang sering digunakan dalam penelitian tentang kewirausahaan (Wilson et al., 2007 dan Souitaris et al., 2007). Para peneliti telah menegaskan bahwa niat kewirausahaan secara efektif dapat memprediksi perilaku kewirausahaan, dan sikap kewirausahaan (Ajzen, 2005). Karena sikap dan niat didasarkan pada persepsi, maka kedua faktor tersebut dapat 
dipelajari (Krueger dan Brazeal, 1994). Oleh karena itu, memelihara sikap dan niat berwirausaha melalui pendidikan kewirausahaan penting dilakukan untuk menjalankan proses mempromosikan kewirausahaan.

Conner \& Armitage (1998) berpendapat bahwa, niat mewakili "motivasi seseorang untuk membuat upaya untuk bertindak atas rencana sadar atau keputusan". Niat berwirausaha adalah motivasi seseorang untuk membuat rencana secara sadar untuk melakukan perilaku dalam mendirikan bisnis. Thompson (2009) telah mendefinisikan niat kewirausahaan sebagai keyakinan diri yang diakui oleh seseorang bahwa, mereka berniat untuk mendirikan usaha bisnis baru dan secara sadar, berencana melakukannya dalam beberapa titik serta di masa depan. Maskud dari niat wirausaha bukan hanya pertanyaan ya atau tidak, tetapi dapat berkisar dari sangat rendah, nol, hingga tingkat niat yang sangat tinggi untuk mendirikan suatu bisnis (Thompson, 2009). Pendapat tersebut berkaitan dengan aturan umum yang didefinisikan oleh Ajzen : Semakin kuat niat yang dimiliki seseorang, semakin mungkin perilaku tersebut di lakukan (Ajzen, 1991). Oleh karena itu, niat kewirausahaan berfungsi sebagai mediator untuk melakukan sebuah tindakan (Fayolle et al., 2006). Penelitian lain juga telah menegaskan bahwa niat adalah prediktor kuat dari perilaku aktual dalam pengaturan terapan lain (Gelderen et al., 2008).

Banyak penulis berpendapat bahwa keputusan untuk menjadi seorang pengusaha dan mendirikan sebuah bisnis, telah melibatkan beberapa perencanaan yang matang dan proses berpikir yang sangat disengaja (Tkachev \& Kolvereid, 1999). Secara khusus mengenai program pendidikan kewirausahaan, niat berlaku sebagai "bukti suatu tindakan dari perilaku yang direncanakan" (Krueger et al., 1993:5). Penerapan konsep niat kewirausahaan tersebut sering digunakan peneliti sebagai ukuran dampak dari pelaksanaan program pendidikan kewirausahaan. Linan dan Chen (2009) dalam penelitiannya, mengukur niat kewirausahaan menggunkan indikator prediksi diri (self-prediction) dan niat murni (pure-intention). Pada penelitian tersebut, Linan dan Chen (2009) menggunakan 6 item pernyataan dalam mengukur variabel niat kewirausahaan yang diacu dalam penelitian ini.

$\begin{aligned} & \text { Ecosystem kewirusahaan dan minat } \\ & \text { berwirausaha } \\ & \text { Terkait }\end{aligned}$ dengan
$\begin{array}{r}\text { ecosystem } \\ \text { kewirausahaan, } \\ \text { bahwa kajian }\end{array}$ yang berfokus pada peran

ecosystem terhadap kewiruashaan mirip dengan kajian yang berbasis pada teori kluster industri. Kajian-kajian tersebut menunjukkan bahwa perusahaan dalam kluster industri akan memperoleh manfaat dari adanya jaringan berbagai perusahaan yang bekerjasama sekaligus bersaing pada satu rantai pasok. Kluster industri akan menghasilkan manfaat dari perputaran pengetahuan. Pada sisi lain ekosistem kewirausahaa memungkinkan terjadinya share pengetahuan, teknologi dan inovasi maupun jaringan bisnis dari satu insitutsi ke insitusi lainnya.

Lebih lanjut Spegel (2005) mengidentifikasi tiga komponen utama dalam ecosystem kewirausahaan, yaitu budaya (cultural), sosial (social) dan material (material). Budaya dimaknai sebagai kepercayaan dasar dan cara pandang terhadap kewirusahaan dalam suatu wilaah. Dalam konteks ini, budaya dapat dilihat dari dua sisi yaitu, perilaku dan sejarah. Aoyama (2009) menjelaskan bawa budaya daerah dapat mempengaruhi aktivitas kewirausahaan dengan membentuk praktek dan norma kewirausahaan yang diterima masyarakat. Sedangkan atribut sosial dalam ekosistem kewirausahaan dimaknai sebagai sumberdaya yang diperoleh dari jaringan sosial yang terdapat dalam sutau masyarakat. Nijkamp (2003) dan Stuart \& Sorenson (2005) mengungkapkan pentingnya jaringan dan modal sosial dalam proses kewirausahaan. Jarngan sosial berperan sebagai saluran pengetahuan baru yang membnatu wirausahawan untuk mengaberpengaruh terhadap cara pandang dan keterampilan kewirausahaan. Atribut terakhir dari ecosystem kewirausahaan adalah material yaitu komponen ecosystem kewirausahaan yang bersifat fisik, baik berupa lokasi, kebijakan atau keberadaan pasar. Dalam konteks ecosystem di suatu daerah Lawton et al (2014) mengidentifikasi empat bentuk dari atribut material kewirausahaan yaitu : keberadaan universitas, fasilitas dan layanan pendukung, kebijakan. 


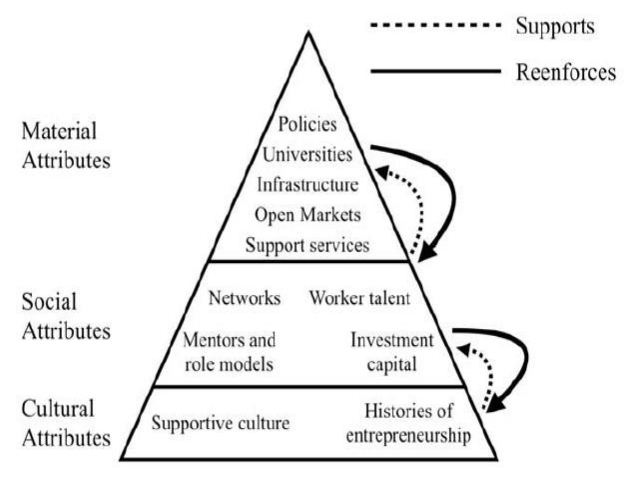

Gambar 1

Atribut dalam Ecosystem Kewiruashaan Sumber : Spegel (2005)

Spegel (2005) juga menjelaskan bagaimana ketiga elemen dari ecosystem kewirausahaan tersebut berinterkasi satu sama lain. Gambar 2 menunjukkan bahwa atribut ecosystem yang paling dasar mendukung atribut yang berada diatasnya dan sebaliknya atribut yang berada diatas memperkuat atribut yang ada dibawahnya. Misalnya, atribut budaya (baik berupa budaya lokal yang menghargai perilaku kewirausahaan atau cerita keberhasilan wirausaha) akan mendukung atribut sosial berupa muncunlnya hubungan sosial yang dapat menjadi media transfer pengetahuan dan inovasi. Munculnya wirausaha yang berhasil akan menghasilkan banyak mentor yang bersedia memberikan bimbingan bagi wirausaha -wirausaha baru. Disisi lain, atribut sosial ini juga akan diperkuat oleh atribut material baik berupa fasislitas fisik maupun regulasi yang ada di daerah tersebut.

\section{METODE PENELITIAN \\ Pendekatan dan jenis Penelitian}

Penelitian ini bertujuan untuk menguji apakah ecosisyem yang sudah terwujud di PT berpengaruh terhadap minat dan sikap kewirausahaan mahasiswa . Penelitian ini dilakukan dengan pendekatan kuantitatif dan bersifat explorative dengan teknik pengumpulan data survei terhadap mahasiswa program studi Administrasi bisnis Angkatan 2019. Populasi dalam penelitian ini adalah mahasiswa Program Studi Administrasi Bisnis Universitas Brawijaya angkatan 2019. Berdaasarkan Pusat Informasi, Dokumentasi, dan Keluhan (PIDK UB, 2019) jumlah mahasiswa Studi Administrasi Bisnis Universitas Brawijaya angkatan 2019 sebanyak 394 mahasiswa. Sampel penelitian adalah sampel jenuh, yaitu semua populasi dijadikan sampel penelitian. Dari 394 kuisoner yang telah di sebar ke responden, 294 kuisoner yang kembali atau tingkat respond rate penelitian ini adalah $75 \%$.

Definisi Operasional Variabel

Definisi operasional dari masing-masing variabel dalam penelitian ini mengacu pada operasionalisasi variabel ecosystem kewirausahaan yang dikembangkan Stam and Spigel (2016)

Tabel 1

Definisi Operasional Variabel

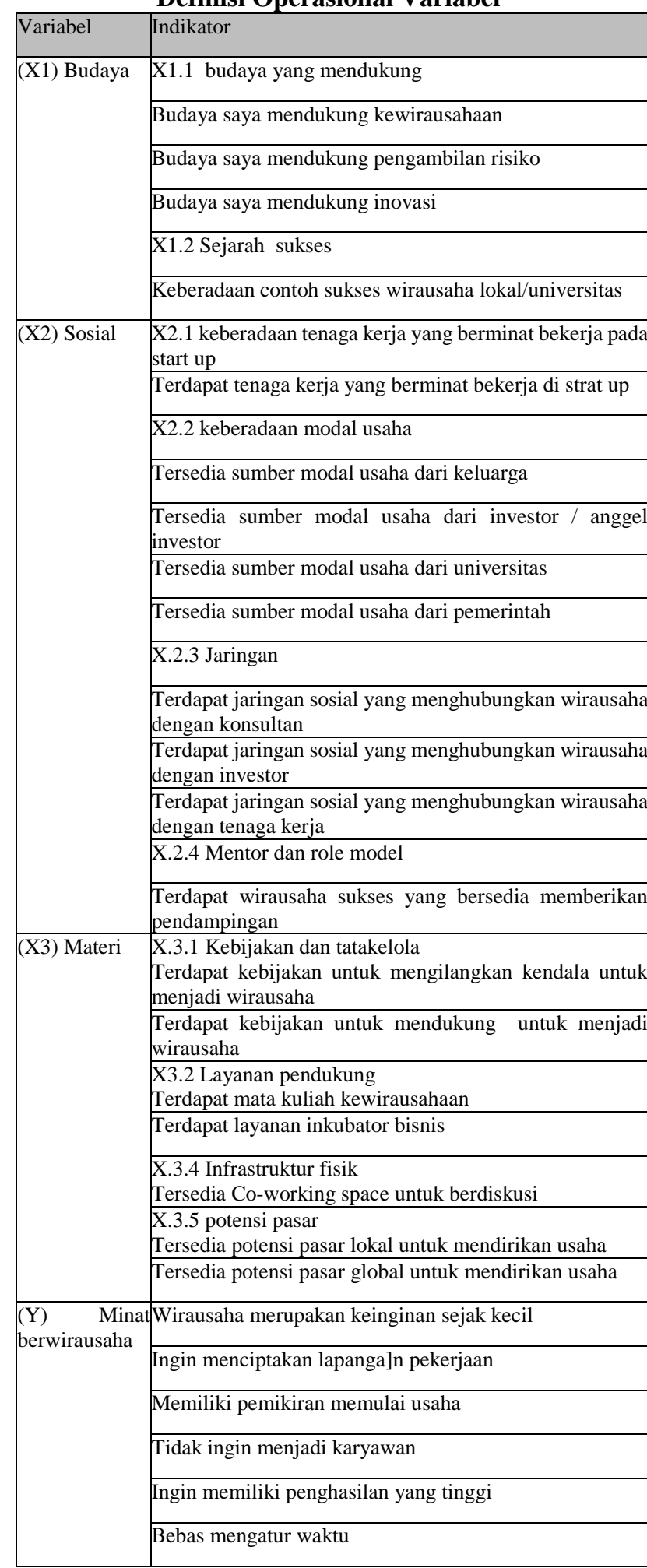


Berdasarkan koefisien korelasi. product moment, nilai koefisen setiap item pertanyaan nilai $r \geq 0,30$, yang berarti setiap item pertanyaan sahih atau valid atau dapat menggambarkan arti sebenarnya dari konsep yang diteliti. Keselurusah item juga dinyatakan reliable karena keseluruhan item memiliki nilai alpha crobach lebih dari 0,6. Nilai alpha crobach lebih besar dari 0.6 bermakna item memiliki keandalan atau konsisten da;am pengukuran.

\section{Analsis data}

Teknik analisis yang digunakan dalam penelitian ini adalah analisis regresi linier berganda. Menurut Sugiyono (2010:77), analisis linier berganda menggambarkan pengaruh linier antara variabel bebas dengan variabel terikat. Alasan peneliti menggunakan analisis ini adalah karena variabel dependen lebih dari satu variabel. Untuk menguji kelayakan model yang dihasilkan dengan menggunakan uji $\mathrm{F}$ pada tingkat $\alpha$ sebesar $5 \%$. Adapun criteria pengujian sebagai berikut.

- Jika nilai $F$ value> 0.05, maka model yang digunakan dalam penelitian tidak layak dan tidak dapat dipergunakan analisis berikutnya.

- Jika nilai $F$ value < 0.05 , maka model yang dugunakan dalam penelitian layak dan dapat dipergunakan analisis berikutnya.

Selain uji F, uji koefisien regresi secara parsial (uji t) juga digunakan untuk mengetahui apakah dalam model regresi variabel independen (X1, X2 dan X3) secara parsial berpengaruh signifikan terhadap variabel dependen (Y). selanjutnya koefisien determinasi (R2)) juga digunakan untuk mengukur seberapa jauh kemampuan model dalam menerangkan variasi variabel dependen. Nilai koefisien determinasi adalah antara nol dan satu. Apabila nilai R2 kecil atau mendekati nol berarti kemampuan variabelvariabel independen dalam menjelaskan variasi variabel dependen sangat terbatas. Sedangkan bila nilai R2 besar atau mendekati satu berarti variabel-variabel independen memberikan kontribusi yang kuat untuk memprediksi variasi variabel dependen (Ghozali 2011:97). Untuk mengetahui besar kontribusi variabel bebas (Budaya (X1), Sosial (X2) dan Materi (X3)) terhadap variabel terikat (Minat Berwirausaaha) digunakan nilai $\mathrm{R} 2$.

\section{HASIL DAN PEMBAHASAN}

Penelitian ini dilakukan di Universitas Brawijaya (UB) yang secara nasional menduduki peringkat 5 secara nasional, peringkat 51 di Asia dan 400 dunia. UB juga dikenal sebagai salah satu Universitas yang memiliki misi menjadi entrepreneurial university. Pencanangan UB menuju Entrepreneurial University dilakukan pada tanggal 2 Juni 2007 dan diikuti pembenahan organisasi BUA (Badan Usaha Akademik) maupun BUNA (Badan Usaha Non Akademik) sebagai Lembaga yang diharapkan mampu menciptakaan ekosistem kewirausahaan. Kedua lembaga ini merupakan cikal bakal berdirinya Badan Pengelola Usaha (BPU) di UB. Apabila BUNA lebih fokus pada aktivitas pengelolaal usaha yang bersifat riil (seperti layanan penginapanapan, layanan kantin, layanan fasilitas kesehatan dan percetakan), BUA berfokus pada proses hilirisasi hasil-hail penelitian dosen untuk menjadi produk atau jasa yang bernilai komersial. Disamping kedua kegiatan tersebut, ecosystem kewirausahaan di UB juga dimanifestasikan pada kegiatan intrakurikuler dengan memberikanmata kuliah kewirausahaan pada semua fakultas maupun kegiatan intrakurikuler yang berupa program Program Kreatif Mahasiswa Kewirausahaan (PKMK), pelatihan kewirausahaan maupun kompetisi model bisnis.

Tabel 2

Karakteristik Responden

\begin{tabular}{|l|l|}
\hline Karakteristik & Porsentase \\
\hline 18 tahun & 214 \\
\hline Perempuan & 181 \\
\hline Jawa Timur & 59 \\
\hline Suku Jawa & 198 \\
\hline Keluarga Non-wirausaha & 149 \\
\hline
\end{tabular}

Untuk mengetahui dampak ecosystem kewirausahaan yang tercipta di UB terhadap minat berwirausaha mahasiswa, penelitian ini melibatkan 294 mahasiswa Program studi Administrasi Bisnis sebagai responden. Karakteristik responden tergambar dalam Table 2. Mayoritas responden berumur 18 tahun (sebanyak 214 responden) dan mayoritas responden adalah perempuan (sebanyak 181) sisanya sebanyak 113 responden adalah laki-laki. Dari sisi latar belakang budaya, 59 responden berasal dari Jawa Timur dan 198 responden berlatar belakang budaya Jawa. Sebanyak 149 responden mahasiswa tidak memiliki latar belakang keluarga yang berwirausaha dan 145 
Mahasiswa memiliki latar belakang keluarga wirausaha. Berdasarkan hal tersebut dapat disimpulkan bahwa, memiliki keluarga yang tidak berlatar belakang wirausaha lebih mendominasi daripada mahasiswa yang memiliki keluarga wirausaha

Penelitian ini menggunakan tiga variabel bebas; variable budaya, variabel social (X2), dan variabel materi (X3) dan variabel minat berwirausaha sebagai variabel terikat. Variabel budaya (X1) diukur menggunakan empat, indikator yaitu : budaya saya mendukung kewirausahaan (X11), budaya saya mendukung pengambilan risiko (X12), budaya saya mendukung inovasi (X13 ) dan keberadaan contoh sukses wirausaha lokal/universitas (X14). Nilai rerata untuk variable X1 adalah 3,9, item pernyataan X13 menunjukkan nilai mean yang paling tinggi yakni sebesar 4,17. Hal ini menunjukkan bahwa tanggapan responden dengan mean tertinggi pada variabel budaya adalah item "budaya saya mendukung inovasi". Item penyataan X12 menunjukkan nilai mean yang paling rendah yakni sebesar 3,63. Hal ini membuktikkan bahwa, pada item ini tanggapan responden memiliki nilai mean terendah pada variabel budaya yaitu item "Budaya saya mendukung pengambilan risiko".

Terkait dengan variable social (X2), hasil penelitian menunjukkan nilai rata-rata keseluruhan jawaban item kuesioner ini sebesar 3,64 . Dengan X21 dengan nilai mean yang paling tinggi yakni sebesar 4,02 dan X23 dan X24, dengan nilai mean paling rendah yakni sebesar 3,36. Hal ini menunjukkan bahwa tanggapan responden dengan mean tertinggi pada variabel sosial adalah item "Terdapat tenaga kerja yang berminat bekerja di start up" dan "Tersedia sumber modal usaha dari investor / angel investo r" dan "Tersedia sumber modal usaha dari universitas" mendapat respond rendah. Variabel bebas selanjutnya adalah variable materi (X3). Mayoritas Responden menyatakan setuju. Nilai rata-rata keseluruhan jawaban item tentang materi kewiraisauahaan adalah 3,88. Item pernyataan X33 menunjukkan nilai mean yang paling tinggi yakni sebesar 4,03. Hal ini menunjukkan bahwa tanggapan responden dengan mean tertinggi pada variabel materi adalah item "Terdapat mata kuliah kewirausahaan". Item penyataan X31 menunjukkan nilai mean yang paling rendah yakni sebesar 3,61. Hal ini membuktikkan bahwa, pada item ini tanggapan responden memiliki nilai mean terendah pada variabel materi yaitu item
"Terdapat kebijakan untuk mengilangkan kendala dalam menjadi wirausaha".

Minat berwirausaha adalah variabel terikat dalam penelitian ini. Hasil penelitian menunjukkan bahwa minat berwirasuaha dikalangan responden relative tinggi yaitu sebesar 4,27 (pada skala 1-5). Nilai rearata tertinggi ditunjukkan oleh item "Ingin memiliki penghasilan yang tinggi" yaitu sebesar 4,73 dan terendah terdapat pada item "Tidak ingin menjadi karyawan" dengan nilai mean sebesar 3,65. Hal ini membuktikkan bahwa, pada item ini tanggapan responden memiliki nilai mean terendah pada variabel materi yaitu item.

\section{Uji Analisis Regresi Linier Berganda}

Analisis data yang digunakan dalam penelitian ini adalah analisis regresi linier berganda yang menggambarkan pengaruh linier antara variabel bebas dengan variabel terikat. Untuk menguji kelayakan model yang dihasilkan dengan menggunakan uji $\mathrm{F}$ pada tingkat $\alpha$ sebesar $5 \%$. Untuk mengukur seberapa jauh kemampuan model dalam menerangkan variasi variabel dependen digunakan nilai koefisien determinasi. Untuk mengetahui kontribusi variabel bebas (Budaya (X1), Sosial (X2) dan Materi (X3) terhadap variabel terikat (Minat Berwirausaaha) digunakan nilai R2, nilai R2. . Dari hasil analisis diperoleh hasil adjusted $\mathrm{R}^{2}$ (koefisien determinasi sebesar 0,336. Artinya bahwa 33,6\% variabel Minat Berwirausaha dipengaruhi oleh variabel bebasnya, yaitu budaya (X1), sosial (X2) dan materi (X3) (Tabel 3). Sedangkan untuk mengetahui apakah dalam model regresi variabel independen (X1, X2, dan X3) secara parsial berpengaruh signifikan terhadap variabel dependen (Y) digunakan uji t. Berdasarkan uji analisis regresi linier berganda secara parsial diketahui terdapat hubungan signifikan antara variabel Budaya (X1) terhadap Niat berwirausaha (Y) dan variabel Materi (X3) terhadab p Niat berwirausaha $(\mathrm{Y})$. Sedangkan pengaruh variabel Sosial (X2) terhadap Niat berwirausaha (Y) tidak signifikan (tabel 4). Dari hasil analisis juga bisa diketahui bahwa penelitian ini mendukung hipotesis yang mengungkapkan bahwa terdapat hubungan signifikan antara variabel Budaya (X1) terhadap Niat berwirausaha (Y) dan hubungan antara variabel Materi (X3) dan Niat berwirausaha (Y). Penelitian ini tidak mendukung hipotesis yang menyatakan terdapat hubungan signifikan antara variabel Sosial (X2) terhadap Niat berwirausaha $(\mathrm{Y})$ 
Tabel 3 Koefisien Korelasi dan Determinasi

\begin{tabular}{|l|l|l|l|}
\hline $\mathrm{R}$ & R Square & Adjusted R Square & Std. Error of the Estimate \\
\hline ,336a &, 113 &, 104 & 3,083 \\
\hline
\end{tabular}

Tabel 4 Hasil Uji t / Parsial

\begin{tabular}{|l|l|l|l|l|l|}
\hline Variabel Terikat & $\begin{array}{l}\text { Varaibel } \\
\text { bebas }\end{array}$ & $\begin{array}{l}\mathrm{t} \\
\text { hitun } \\
\mathrm{g}\end{array}$ & $\begin{array}{l}\mathrm{t} \\
\text { Tab } \\
\mathrm{el}\end{array}$ & Sig. & Keterangan \\
\hline \multirow{3}{*}{$\begin{array}{l}\text { Minat } \\
\begin{array}{l}\text { Berwirausaha } \\
\text { (Y) }\end{array}\end{array}$} & $\mathrm{X} 1$ & $\begin{array}{l}2,25 \\
7\end{array}$ & $\begin{array}{l}1.98 \\
1\end{array}$ & $\begin{array}{l}0,0 \\
25\end{array}$ & Signifikan \\
\cline { 2 - 6 } & $\mathrm{X} 2$ & $\begin{array}{l}0,71 \\
3\end{array}$ & $\begin{array}{l}1.98 \\
1\end{array}$ & $\begin{array}{l}0,4 \\
76\end{array}$ & $\begin{array}{l}\text { Tidak } \\
\text { Signifikan }\end{array}$ \\
\cline { 2 - 6 } & $\mathrm{X} 3$ & $\begin{array}{l}4,48 \\
9\end{array}$ & $\begin{array}{l}1.98 \\
1\end{array}$ & $\begin{array}{l}0,0 \\
00\end{array}$ & Signifikan \\
\hline
\end{tabular}

Hasil penelitian ini mengkonfirmasi pendapat Spegel (2005) yang menjelaskan bahwa ecosystem kewirausahaan, yang terdiri dari dari atribut budaya (cultural), sosial (social) dan material (material) berpengaruh terhadap kewiausahaan. Namun penelitian ini tidak mendukung hubungan signifikan antara atribut sosial dan kewirausahaan. Padahal menurut Nijkamp (2003) dan Stuart \& Sorenson (2005) atribut sosial juga berkontrbusi terhadap proses kewirausahaan. Atribut sosial berperan sebagai saluran pengetahuan baru yang membantu wirausahawan untuk mengaberpengaruh terhadap cara pandang dan keterampilan kewirausahaan. Terkait dengan tidak signifikannya hubungan antara atribut sosial dan minat berwirausaha secara empiris dapab7dijelaskan sebagai berikut : Pertama, populasi dari penelitian ini adalah mahasiswa program studi Admistrasi Bisnis Angkatan 2019 -gyang berarti mereka masih menjalani aktivitas akademik di Universitas selama enam bulan (satu semester) sehingga belum banyak mengetahui dan terlibat didalam ecosystem kewirausahaan. Sehingga meskipun nilai rerata atribut budaya tinggi, nilai rerata sosial relatif rendah karena mereka belum mengetahui atau terlibat dalam jaringan sosial yang terdapat di universitas. Kedua, latar belakang keluarga mayoritas respondent berasal dari keluarga nonwirausaha. Beberapa studi membuktikan bahwa latar

Hasil Model hipotesis dalam penelitian ini tergambar dalam gambar 2

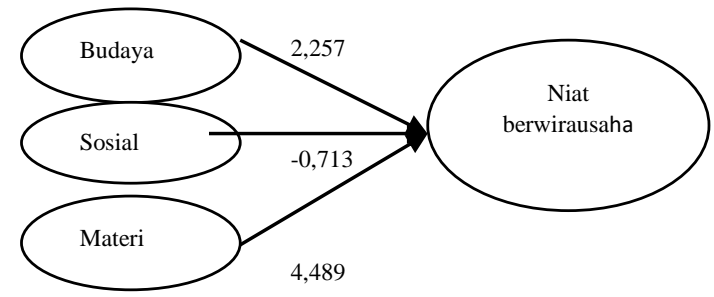

Gambar 2 Model Hasil uji Hipotesis belakang profesi orang tua berhubungan erat dengan pilihan untuk menjadi wirausaha. Penelitian yang mendukung statemen tersebut adalah penelitian Singh \& DeNoble (2003) yang mengungkapkan bahwa pekerjaan orang terdekat dan kelurga akan mempengaruhi pilihan karir seseorang dan penelitian Klandt (1984) yang menemukan bahwa profesi ayah memeliki pengaruh pada keputusan anak laki-laki dan perempuan untuk memilih pekerjaan sedangkan pengaruh ibu hanya terbatas pada pekerjaan anak perempuan. Dari kedua penelitian tersebut relavan dengan hasil penelitian ini bahwa karena mayoritas latar belakang pekerjaan orang tua tidak berasal dari profesi wirausaha, maka pilihan pekerjaan mereka juga tidak terkait dengan wirausaha.

Ketiga, penciptaan ecosystem kewirausahaan di Universitas Brawijaya masih berada tahap material (atau kegiatan yang bersifat fisik). Secara empiris di Universitas Brawijaya telah terdapat program sebagai implementasi misi Universitas sebagai entpreneurial University baik yan bersifat jangka panjang (proes hilirisasi hasil peneitian maupun bersifat jangka penjeng untuk menghasilkan mahasiswa wirausaha. Apabila dilihat dari indikator atributu sosial yang meliputi ; ketersediaan sumber modal usaha dari keluarga, ketersediaan sumber modal usaha dari investor / anggel investor, ketersediaan sumber modal usaha dari universitas, ketersediaan sumber modal usaha dari pemerintah, ketersediaan jaringan sosial yang menghubungkan wirausaha dengan konsultan, investor, tenaga kerja, dan ketersediaan wirausaha sukses yang bersedia memberikan pendampingan.

\section{KESIMPULAN DAN SARAN Kesimpulan}

Dari hasil penelitian dapat diambil beberapa kesimpulan, yaitu : (1) Universitas Brawijaya sebagai Perguruan Tinggi yang berorientasi kewirausahaan telah menciptakan ecosystem yang mendorong munculnya minat berwirasuaha berupa kegaiatan intra dan ekstrakurikuler. (2) Dari analisis regresi linear berganda diketahui bahwa terdapat pengaruh significant antara semua variable ecosystem kewirausahaan yang terdiri dari variable budaya, variable materi dan variable social terhadap minat berwira usaha secara simultan (3) Secara parsial, hanya variable budaya (X1) dan variabel materi (X3) yang memiliki pengaruh significant terhadap niat berwirausaha $(\mathrm{Y})$ sedangkan variabel sosial 
(X2) tidak berpengaruh secara terhadap minat berwirausaha (Y).

Saran

Terkait hasil penelitian, rekomendasi yang bisa diajukan adalah : (1) Penelitian ini menggunakan variable budaya, variable materi dan variable social dalam menjelaskan ecosystem kewirausahaa sehingga masih perlu banyak studi yang menggunakan variabel lain dalam mengukur kewirausahaan dan melibatkan mahasiswa nonbusines sebagai sampelnya. (2) Terkait dengan bervariasinya minat berwirasuaha dikalangan mahasiswa, maka perlu dilakukan seleksi khusus terhadap mahasiswa yang memiliki orientasi kewirausahaan agar program pengembangan kewirusahaan bis lebih efektif.

\section{DAFTAR PUSTAKA}

Acs, Z.J., Desai, S. and Hessels, J., 2008. Entrepreneurship, economic development and institutions. Small business economics, 31(3), pp.219-234.

Ajzen, I., 1991. The theory of planned behavior. Organizational behavior and human decision processes, 50(2), pp.179211.

Basu, A., dan Virick, M. 2008. Assessing Entrepreneurial Intentions Amongst Students: A Comparative Study.

Bosma, N.S. and Levie, J., 2010. Global Entrepreneurship Monitor 2009 Executive Report.

Conner, M. and Armitage, C.J., 1998. Extending the theory of planned behavior: A review and avenues for further research. Journal of applied social psychology, 28(15), pp.1429-1464.

Ghozali, Imam, 2005, Analisis Multivariate dengan program SPSS, Badan Penerbit Universitas Diponegoro.

Hofer, A.R. and Baur, P., 2018. Graduate entrepreneurship support: what higher education institutions do, and how government can support them. Lessons from Hungary and Ireland. In Entrepreneurship and Local Economic Development (pp. 226-248). Routledge.

Izedonmi, Prince Famous and Chinonye Okafor, 2010, The Effect of Entrepreneurship Education on Students' Entrepreneurial Intentions, Global Journal of
Management and Business Research, Vol.10, Iss.6/August, pp.49-60.

Krueger, N.F. and Carsrud, A.L., 1993. Entrepreneurial intentions: applying the theory of planned behaviour. Entrepreneurship \& Regional Development, 5(4), pp.315-330

Kuratko, D.F., 2005. The emergence of entrepreneurship education: Development, trends, and challenges. Entrepreneurship theory and practice, 29(5), pp.577-597.

Liñán, F. and Chen, Y.W., 2009. Development and cross-cultural application of a specific instrument to measure entrepreneurial

intentions. Entrepreneurship theory and practice, 33(3), pp.593-617.

Nieman, G. and Nieuwenhuizen, C., 2009. Entrepreneurship: A South african perspective. Van Schaik.

Do Paço, A., Ferreira, J. M., Raposo, M., Rodrigues, R. G., \& Dinis, A. 2015. Entrepreneurial intentions: is education enough?. International Entrepreneurship and Management Journal, 11(1), 57-75.

Peng, M.W., 2016. Global business. Cengage Learning.

Schumpeter, J.A., 1934. Change and the Entrepreneur. Essays of JA Schumpeter.

Shane, S. and Venkataraman, S., 2000. The promise of entrepreneurship as a field of research. Academy of management review, 25(1), pp.217-226.

Sieger, P., Fueglistaller, U. and Zellweger, T., 2016. Student entrepreneurship 2016: Insights from 50 countries.

Souitaris, V., Zerbinati, S., \& Al-Laham, A. 2007. Do entrepreneurship programmes raise entrepreneurial intention of science and engineering students? The effect of learning, inspiration and resources. Journal of Business venturing, 22(4), 566-591.

Spegel, Ben, 2005, The Relational Organization of Entrepreneurial Ecosystems, Entrepreneurship Theory and Practise, June. 
Singh and DeNoble, 2003, Views on Selfemployment and Personality: an Exploratory Study, Journal pf Developmental Entrepreneurship, 8 (3), 265-281.

Stam, E. and Spigel, B., 2016. Entrepreneurial ecosystems and regional policy. Sage handbook for entrepreneurship and small business. London: SAGE.

Stuart, T.E., \& Sorenson, O., 2005, Social networks and entrepreneurship. In S.A. Alvarez, R. Agarwal, \& O. Sorenson (Eds.), Handbook of entrepreneurship research (pp. 233-252). New York: Springer.

Tubbs, M.E., Boehne, D.M. and Dahl, J.G., 1993. Expectancy, valence, and motivational force functions in goalsetting research: An empirical test. Journal of Applied Psychology, 78(3), p.361.

Tokila, A. and Tervo, H., 2011. Regional differences in returns to education for entrepreneurs versus wage earners. The Annals of Regional Science, 47(3), pp.689-710.

Wilson, F., Kickul, J., \& Marlino, D. 2007. Gender, entrepreneurial self-efficacy, and entrepreneurial career intentions: Implications for entrepreneurship education. Entrepreneurship theory and practice, 31(3), 387-406. 